\title{
Sedimentary geology and biostratigraphy of the Mianwali Formation, Kala Chitta Range, Northern Pakistan
}

\author{
Kaleem Akhtar Qureshi ${ }^{1}$, Ali Nasir Fatmi ${ }^{1}$, Riaz Ahmed Sheikh ${ }^{2}$, and Aftab Ahmad Butt ${ }^{2}$ \\ ${ }^{1}$ Geological Survey of Pakistan, 16-G, Model Town, Lahore, Pakistan \\ ${ }^{2}$ Institute of Geology, Punjab University, Lahore - 54590, Pakistan
}

\begin{abstract}
Microfacies analysis and ammonite biostratigraphy of the Mianwali Formation of the Kala Chitta Range were worked out on the basis of stratigraphic sections from Chak Jabbi and Bagh. Four microfacies were identified from the Chak Jabbi section while ammonite biostratigraphy was studied from both the sections. Filamentous bivalves in micrite deposited along a shelf margin below normal wave base represent the first microfacies. The second microfacies contains bioclastic wackestone deposited in an open marine environment of normal salinity. The third microfacies consists of lime mudstone formed in a stressed environment of lagoonal conditions, whereas the fourth microfacies of dolomitised carbonate mudstone was formed by the diagenetic dolomitisation of the third microfacies.

The new collection of ammonites includes Arctoceras tuberculatum, Anakashmirites aff. evolutus, Meekoceras gracilitatis, Stephanites sp., Pseudoceltites sp., Subvishnuites aff. welteri, Arnautoceltites sp., Owenites sp. indet, Subvishnuites aff. enveris, Pseudosageceras sp. indet, Paranannites sp., Subcolumbites sp., Anasibrites sp., and Pseudaspidites sp. confirming the already known Sctythian age of the Mianwali Formation.
\end{abstract}

\section{INTRODUCTION}

The stratigraphic name - Mianwali Formation (type locality: the Nammal Gorge, Mianwali Town, Salt Range) was formalised by the Stratigraphic Committee of Pakistan (1973) for the part of the Kioto Limestone of Cotter (1933) in the Kala Chitta Range. Detailed sampling for microfacies analysis and environmental interpretation was done from the Chak Jabbi section (Fig. 1 and 2), whereas ammonites were collected both from Chak Jabbi and Bagh for age evaluation. The present study is the first of its kind in terms of microfacies studies and ammonite biostragraphy.

\section{MICROFACIES}

The following four microfacies were identified from the $35 \mathrm{~m}$ thick carbonate section of the Mianwali Formation from Chak Jabbi.

\section{Filamentous bivalve in micrite (MF 1)}

This facies is mainly a bioclastic wackestone/ packstone (biomicrite). The bioclasts are thin-shelled bivalves, in parts closely packed (packstone) and, at places, scattered (wackestone) and randomly distributed. Some minaxon spicules are also found. In the field, poorly preserved ammonoids are frequently observed. There is no preferred orientation of these bioclasts.

\section{Interpretation}

Wilson (1975) described such facies as the result of sudden extinction of pelagic bivalves with resulting sea bottom deposition of tremendous number of shells, which form thin coquina layers and pockets in otherwise very fine-grained sediments. Wilson further pointed out that the thin-shelled pelagic bivalve accumulations are common in Triassic- Jurassic offshore basinal settings. 
Kaleem Akhtar Qureshi et al.

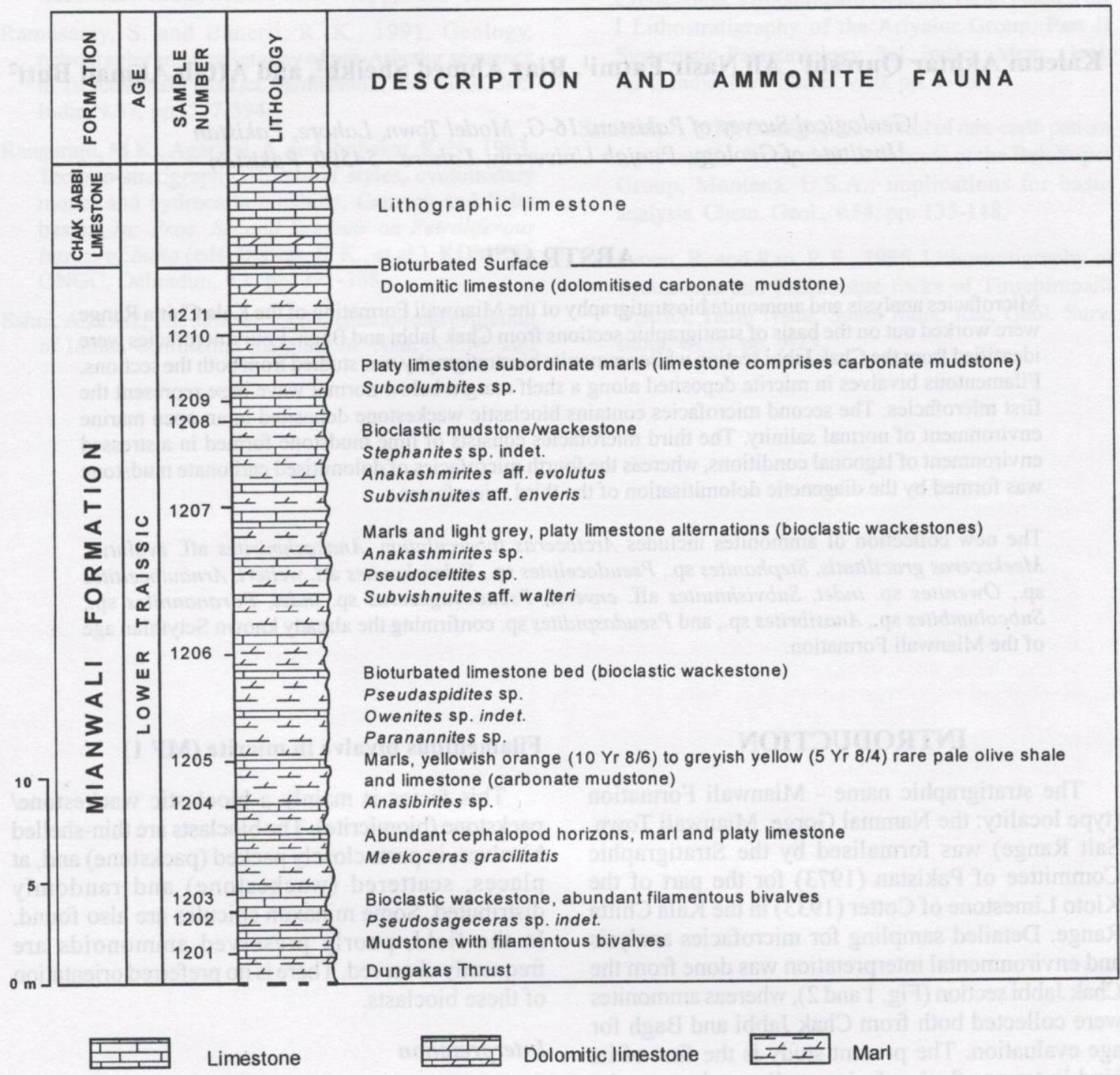

Fig. 1: Lithostratigraphic section of the Mianwali Formation (Lower Triassic) north of Chak Jabbi Rest House, District Attock $\left(33^{\circ} 42^{\prime} \mathrm{N}\right.$ and $\left.72^{\circ} 16^{\prime} \mathrm{E}\right)$ 
Sedimentary geology and biostratigraphy of Mianwali Formation, Northern Pakistan

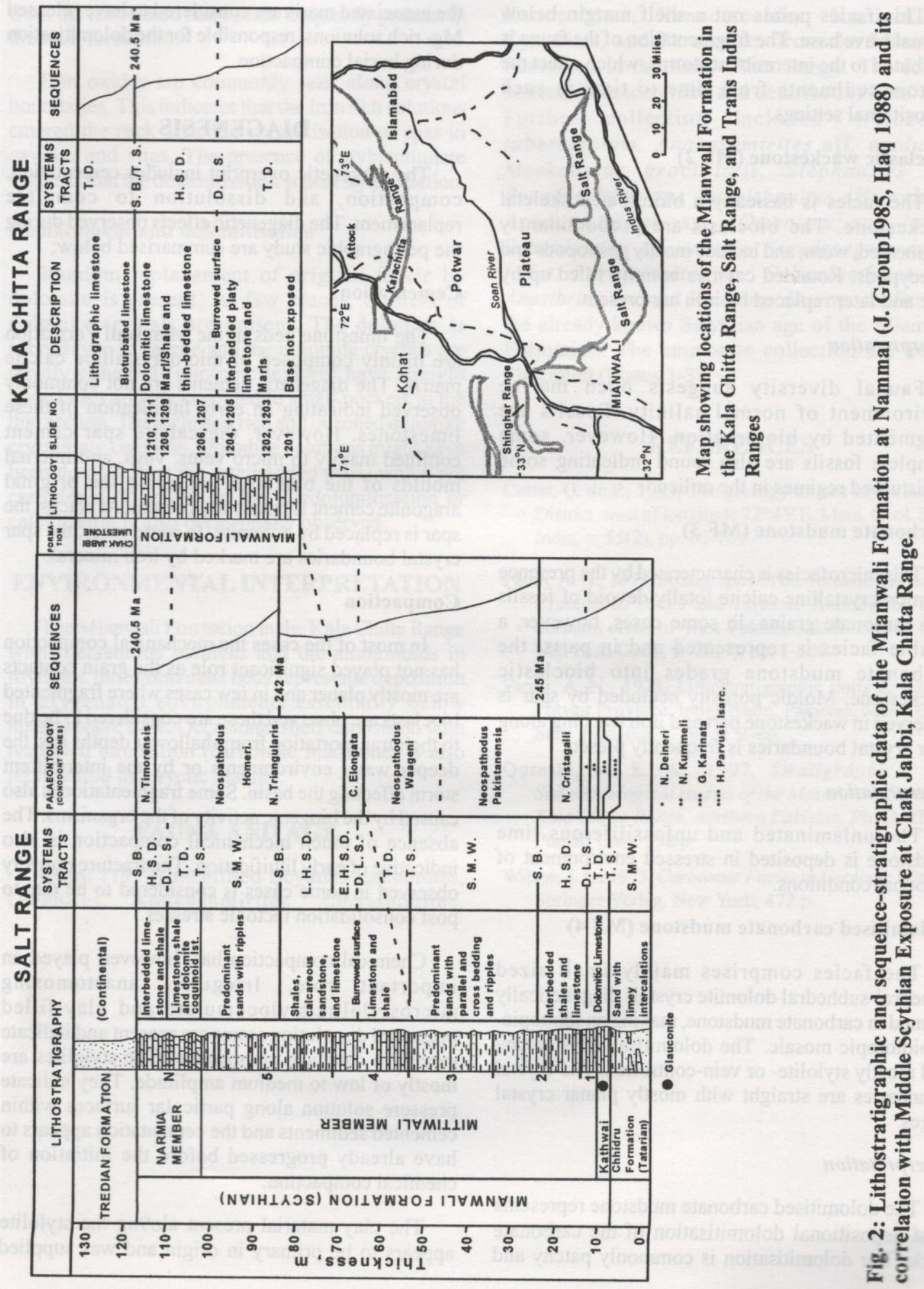


This facies points out a shelf margin below normal wave base. The fragmentation of the fauna is attributed to the intermittent storms, which affect the bottom sediments from time to time in such depositional settings.

\section{Bioclastic wackestone (MF 2)}

The facies is basically a bioturbated skeletal wackestone. The bioclasts are predominantly fragmented, worn, and include mostly gastropods and pelecypods. Rounded cavities initially filled up by spar and later replaced by iron are present.

\section{Interpretation}

Faunal diversity suggests open marine environment of normal salinity. Fossils are fragmented by bioturbation. However, some complete fossils are also found indicating some undisturbed regimes in the milieu.

\section{Carbonate mudstone (MF 3)}

This microfacies is characterised by the presence of microcrystalline calcite totally devoid of fossils and carbonate grains. In some cases, however, a double facies is represented and in parts, the carbonate mudstone grades into bioclastic wackestone. Moldic porosity occluded by spar is observed in wackestone part and iron leaching along spar crystal boundaries is frequently present.

\section{Interpretation}

The unlaminated and unfossiliferous lime mudstone is deposited in stressed environment of lagoonal conditions.

\section{Dolomitised carbonate mudstone (MF 4)}

The facies comprises mainly small sized euhedral-subhedral dolomite crystals diagenetically formed in carbonate mudstone, making an idiotopichypidiotopic mosaic. The dolomitisation is patchy and mostly stylolite- or vein-controlled. The crystal boundaries are straight with mostly planar crystal edges.

\section{Interpretation}

The dolomitised carbonate mudstone represents post-depositional dolomitisation of the carbonate rock. The dolomitisation is commonly patchy and the associated marls are considered to have released Mg-rich solutions, responsible for the dolomitisation during burial compaction.

\section{DIAGENESIS}

The diagenetic overprint includes cementation, compaction, and dissolution to complete replacement. The diagenetic effects observed during the petrographic study are summarised below:

\section{Cementation}

The limestone beds in the Mianwali Formation are mainly composed of microcrystalline calcite matrix. The diagenetic cements are not commonly observed indicating an early lithification of these limestones. However, the calcite spar cement confined mainly to micro veins, vugs, and internal moulds of the bioclasts, replacing the original aragonite cement is frequently present. At places, the spar is replaced by dolomite. In some cases, the spar crystal boundaries are marked by iron mineral.

\section{Compaction}

In most of the cases the mechanical compaction has not played significant role as the grain contacts are mostly planer and in few cases where fragmented bioclasts are observed these are considered to be due to their transportation from shallower depths into the deeper water environments or by the intermittent storm affecting the basin. Some fragmentation is also caused by the biogenic activity of the organisms. The absence of much mechanical compaction is also indicative of early lithification. The fracture porosity observed in some cases is considered to be due to post consolidation tectonic stresses.

Chemical compaction has, however, played an important role. Irregular, anastomosing microstylolite/stylocumulate and clay-filled pressured dissolution seams are present and indicate extensive chemical compaction. The stylolites are mostly of low to medium amplitude. They indicate pressure solution along particular surfaces within cemented sediments and the cementation appears to have already progressed before the initiation of chemical compaction.

The clay material present alo9ng the stylolite appears to be primary in origin and was supplied 
from the associated marl/shale frequently present in the rock formation.

Iron oxides are commonly seen along crystal boundaries. This indicates that the iron rich solutions entered the rock after the crystallisation of spar in cavities and vugs. The presence of stylocumulate suggests that the dolomitisation is post stylolitisation.

\section{Replacement and dolomitisation}

Random replacement of original fabric by dolomite is present. At few places, clusters of dolomite crystals are present. The dolomite is subordinate to calcite and the dolomite crystals are mostly euhedral (idiotopic texture) have straight boundaries and are confined to small pockets in the thin section. The inclusion rich and unzoned dolomite crystals are common. Dolomite solutions might have been derived from the interbedded marls which are considered to be rich in $\mathrm{Mg}$. Dedolomitisation or calcitisation is also occasionally observed.

\section{ENVIRONMENTAL INTERPRETATION}

The Mianwali Formation in the Kala Chitta Range with filamentous bivalves and the ammonoids in rhythmic limestone/marl beds represents deposition in oxygenated environments essentially below normal wave base. Occasional shelf deposition with restricted circulation (carbonate mudstone) is also represented in a cyclic manner.

\section{FAUNA AND AGE}

Fatmi (1972) identified Scythian ammonites, Owenites, Anokashmirites, subvishnuites,
Xenoceltites, Xenodiscoides, Koninckites, Kymatites, and Paranorites from the Mianwali Formation in the Kala Chitta Range. The fossils collected are identified and described (Plates 1-3). Further collection included Arctoceras tuberculatum, Anakashmirites aff. evolutus, Meekoceras gracilitatis, Stephanites sp., Pseudoceltites sp., Subvishnuites aff. welteri, Arnautoceltites sp., Owenites sp. indet, Subvishnuites aff. enveris, Pseudosageceras sp. indet, Paranannites sp., Subcolumbites sp., Anasibrites sp., and Pseudaspidites sp. confirming the already known Sctythian age of the Mianwali Formation. The ammonite collection are newly illustrated (Plates 1-3).

\section{REFERENCES}

Cotter, G. de P., 1933, The geology of part of the Attock District, west of longitude $72^{\circ} 45^{\prime} \mathrm{E}, \mathrm{Mem}$. Geol. Surv. India, v. 55(2), pp. 63-163.

Fatmi, A. N., 1972, Stratigraphy of the Jurassic and Lower Cretaceous rocks and Jurassic Ammonites from northern areas of West Pakistan, Bull. British Mus. Nat. Hist. Geol., v. 20(7), pp. 1-380.

Fatmi, A. N., 1973, Lithostratigraphic units of KohatPotwar Province, Indus Basin, Pakistan, Mem. Geol. Surv. Pakistan, v. 10, pp. 1-80.

Qureshi, M. K. A., 1997, Stratigraphical and Sedimentological studies of the Mesozoic rocks of the Kala Chitta Range, northern Pakistan, Ph. D. Thesis Punjab Univ. $552 \mathrm{p}$.

Wilson, J. L., 1975, Carbonate Facies in Geologic History, Springer-Verlag, New York, 472 p. 
Kaleem Akhtar Qureshi et al.

\section{Plate 1}

1: Subvishnuites aff. walteri, Spath (G. S. P. Coll. B. 710), Chak Jabbi (slightly enlarged)

2 and 4: Arnautoceltites sp. ( G.S.P. Coll. B. 738), Bagh

3 and 5: Owenites sp. (G.S.P. Coll. 713), Chak Jabbi

6: Subvishnuites aff. enveris (Arthaber) (G.S.P. Coll. B. 707), Chak Jabbi

7 and 9: Pseudosageseras sp. (G.S.P. Coll. B. 702), Chak Jabbi

8: Arctoceras tuberculatum, White (G.S.P. Coll. B. 735), Bagh

10: Paranannites sp. (G. S. P. Coll. B.715), Chak Jabbi (slightly enlarged)

\section{Plate 2}

1: Subcolumbites sp. (G. S. P. Coll. B. 716), Chak Jabbi

2: Anakashmirites aff. evolutus (Diener) (G. S. P. Coll. B. 720), Chak Jabbi.

3: Anasibirites sp. (G. S. P. Coll. B. 729)

4 and 8: Meekoceras gracilitatis, White (G.S.P. Coll. B. 727), Chak Jabbi

5: Paranannites sp. (G. S. P. Coll. B. 715), Chak Jabbi

6: Stephanites sp. (G. S. P. Coll. B. 733)

7: Pseudoceltites sp. (G.S.P. Coll. B. 708). Chak Jabbi.

9: Pseudaspidites sp. (G.S.P. Coll. B. 711). Bagh.

\section{Plate 3}

1, 2, and 4: Anakashmirites sp. (G. S. P. Coll. B.721), Chak Jabbi (slightly enlarged)

3: Pseudaspidites sp. (G. S. P. Coll. B. 712), Chak jabbi

5: Pseudoceltites sp. (G. S. P. Coll. B. 707: natural size and B. 739: slightly enlarged), Chak Jabbi

Note: All figures are of natural size unless otherwise indicated. 


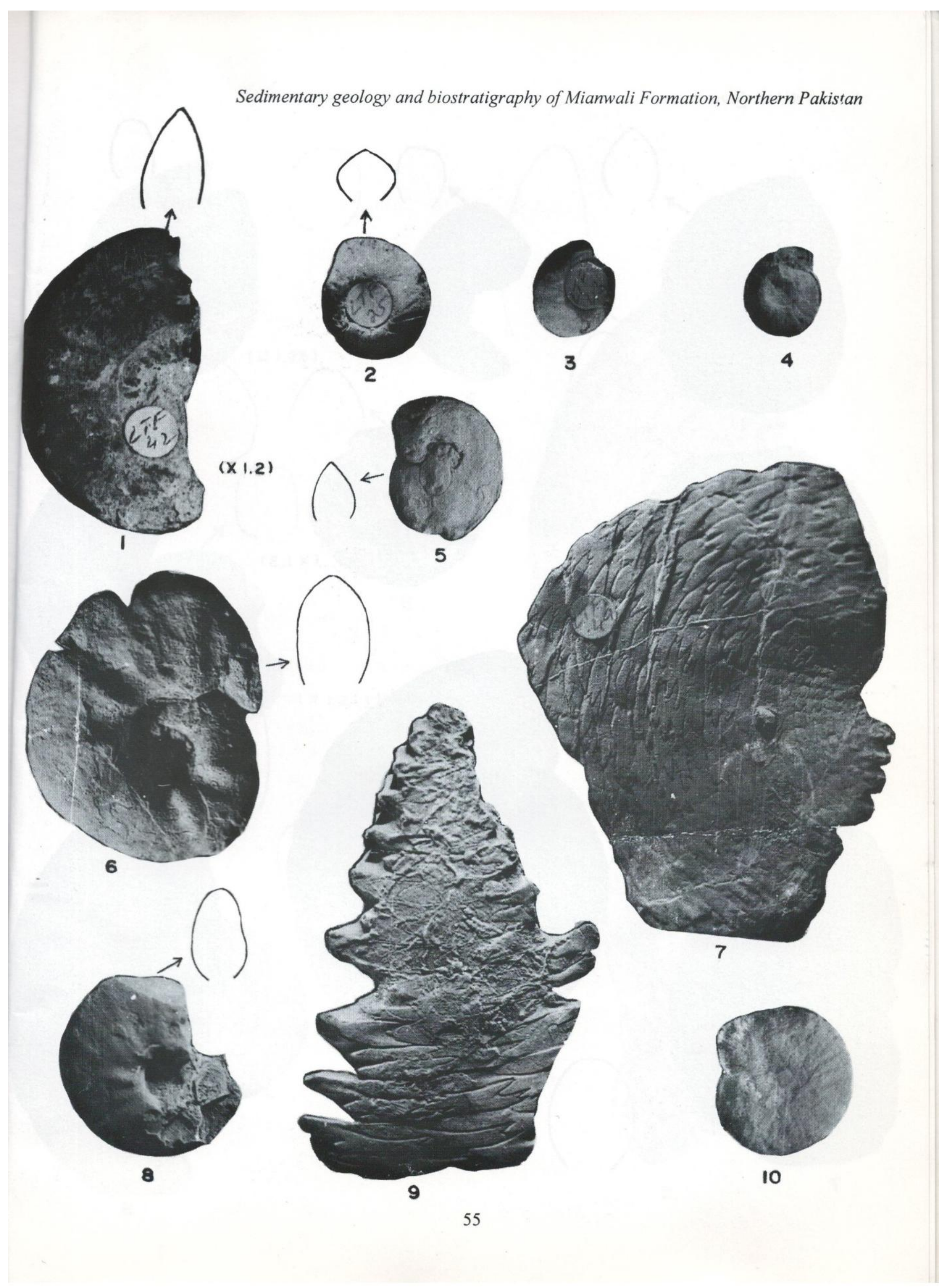




\section{Kaleem Akhtar Qureshi et al.}
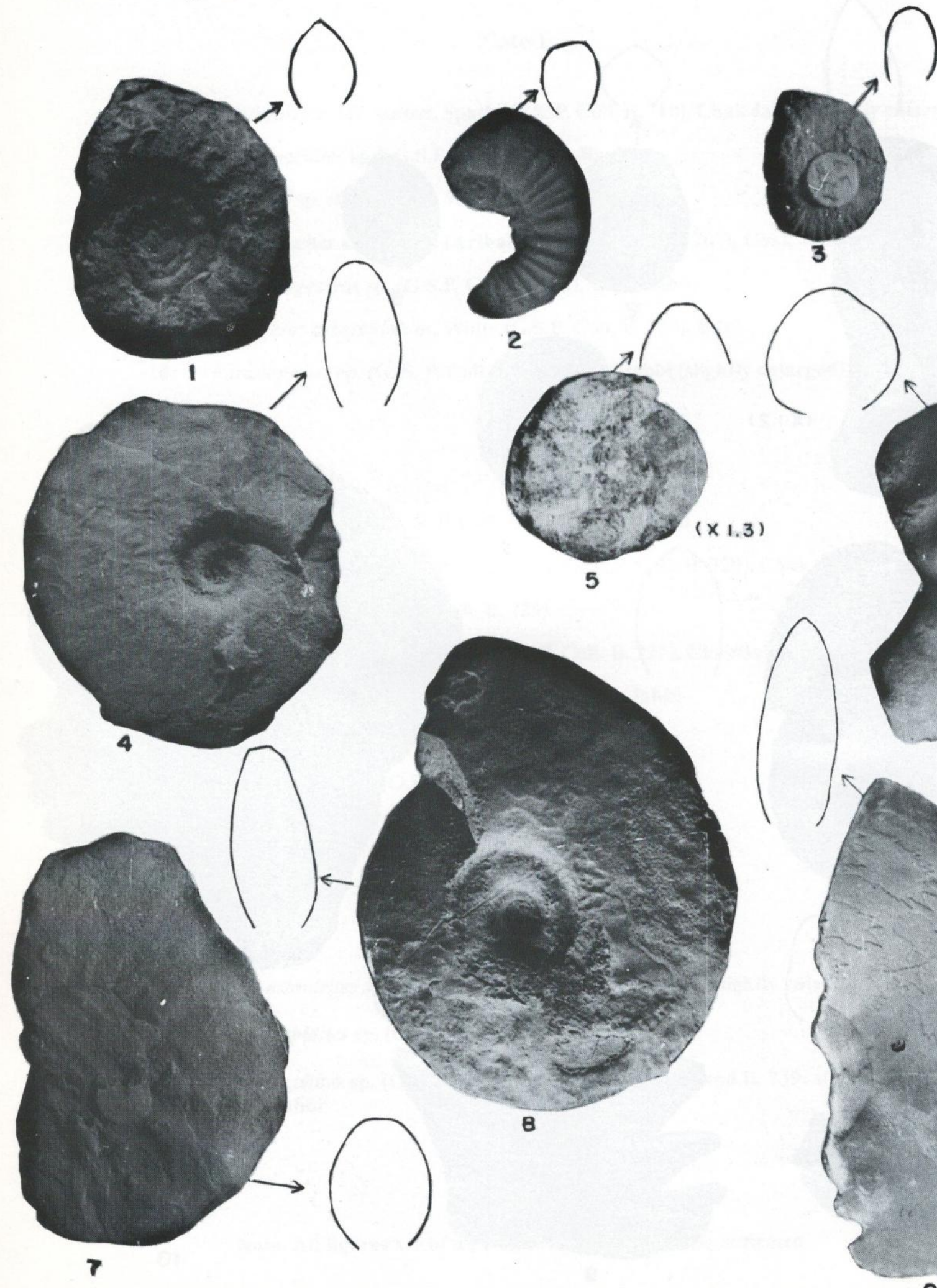
Sedimentary geology and biostratigraphy of Mianwali Formation, Northern Pakistan
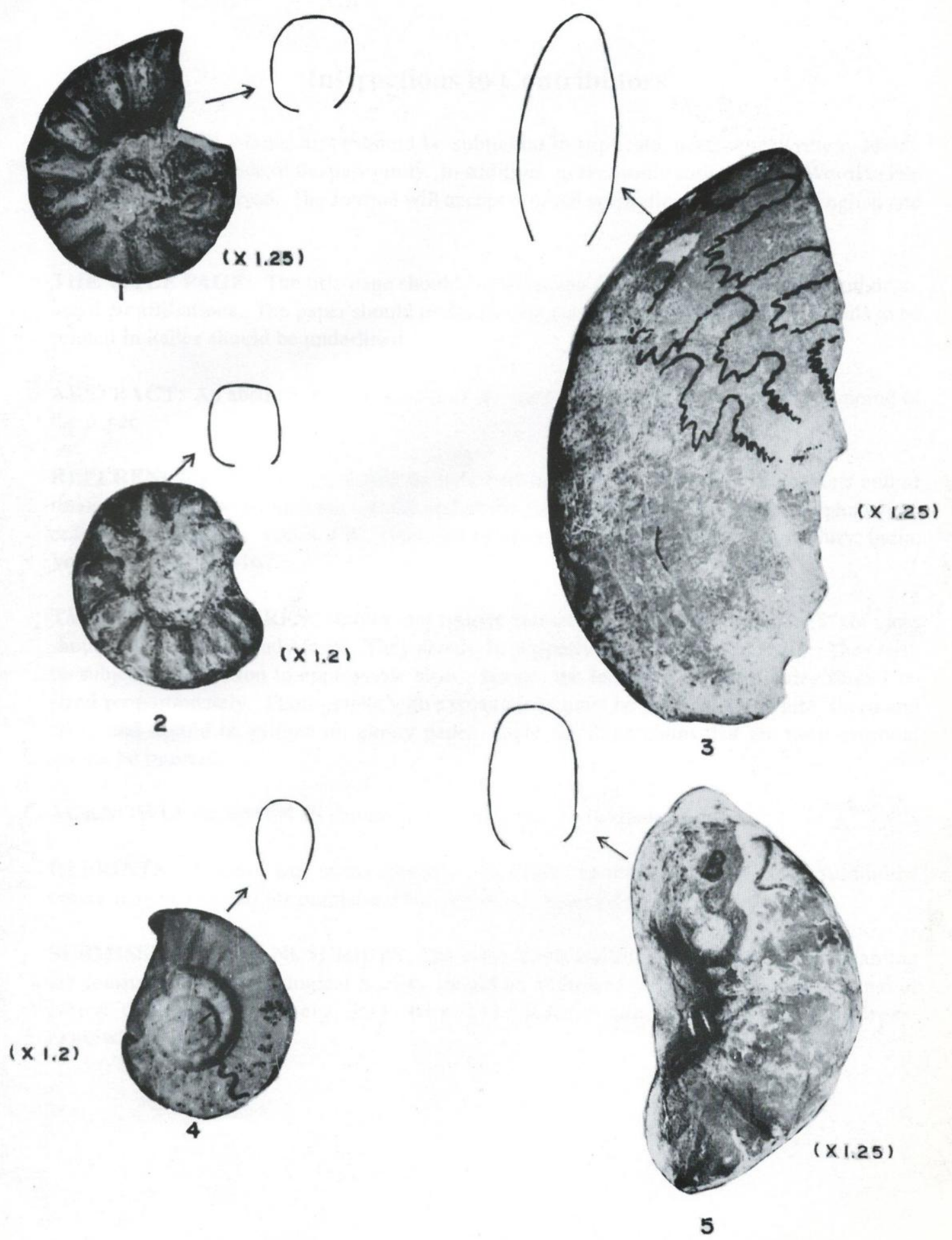